\title{
Modernization of historical houses in Sopot: a case study
}

\author{
J. Poplatek \\ Faculty of Architecture, Gdansk University of Technology, Poland
}

\begin{abstract}
Sopot is the best-known summer health resort in Poland. The city is unique regarding not only its location and natural values, but also its outstanding residential architecture, which dates back to the end of the 19th and the beginning of the 20th century. After the Second World War most of the houses were taken away from their owners (they were nationalized). Deprived of their owners' care, they became more and more degraded and decrepit over the years. This paper covers architectural and building issues, presenting possible actions to be undertaken, aiming at reviving the former splendour and cultural value of the historical houses. It refers to functional arrangement, construction, composition of façades, refurbishment of architectural elements and details. The aforementioned issues have been analysed on the basis of a selected modernization project of the historical house, which was accomplished in Sopot. Keywords: historical building modernization and refurbishment.
\end{abstract}

\section{Introduction}

Sopot, beautifully situated on the Baltic Sea, is the best-known summer resort in Poland. The city is unique with regard not only to its location and natural values, but also to its outstanding residential architecture, which dates back to the end of the 19th and the beginning of the 20th century. Influences of Art Nouveau and Neo-gothic styles predominate in historic residential architecture of the city. We can also find houses built in the Romantic style, as well as examples of summer architecture with characteristic wooden verandas, bay windows, balconies, and soaring turrets decorated with Art Nouveau details (figs 1 and 2).

The old residential architecture of Sopot survived the Second World War without major damage and at present constitutes a historic image of a sea resort, unique in the country. This historic image of Sopot is a valuable part of cultural 


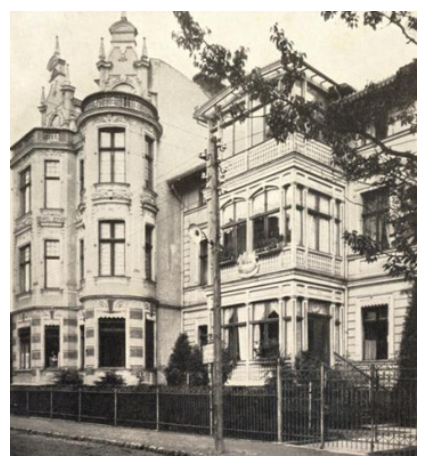

Figure 1: Façade of Villa Germania, ca. 1912, photo courtesy: archives of the Museum of Sopot.

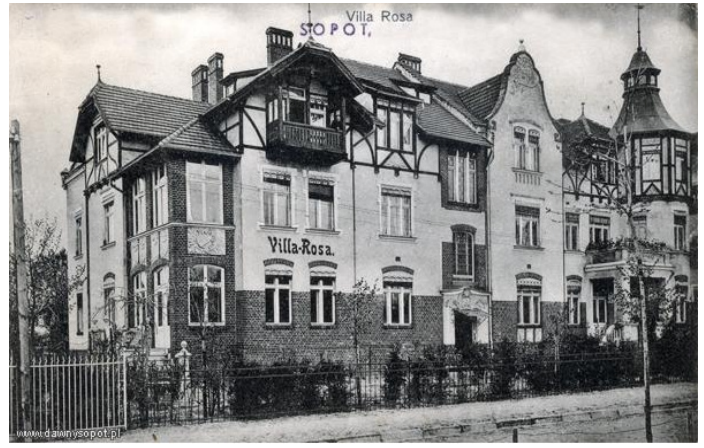

Figure 2: $\quad$ Façade of Villa Rosa, ca. 1910, photo courtesy: archives of the Museum of Sopot.

heritage. Therefore, its preservation and cultivation has to be perceived as extremely important.

After the Second World War the majority of private tenement houses, residences and single-family homes were taken away from their owners and became municipal property. Municipalisation of private real property was common practice in Poland in the years following the Second World War, and Sopot did not avoid it, either. The communist authorities, struggling against lack of flats, quartered more people in the requisitioned buildings than was appropriate, taking into consideration their living area and functional layout. As a result, big flats, which sometimes occupied the entire floor in tenement houses, were chaotically divided into smaller ones. Single-family homes met with a similar fate. It often happened that, in one building, people who lived in a few flats shared one kitchen and one bathroom. This degradation concerned not only the functional layout, but the entire historic structural substance, architectural details and elements of interior décor. During the following decades the technical condition of the houses, with no owners to ensure their proper maintenance, steadily deteriorated. There were no scheduled renovation works, only makeshift 
and fragmentary repairs arising from installation failure or leaking roof. Disregard for architecture dating back to the turn of 19th and 20th century was another adverse factor which, in extreme cases, led to demolition of historic buildings in the course of misconceived "city clean-up".

This was the situation until the beginning of the 1990s, when Poland regained its sovereignty and became a fully democratic country. This was the perfect time to finally compensate for many years of negligence. Residents of severely degraded multifamily buildings gradually became their owners, at the same time obtaining legal rights to re-establish the appropriate quality of the houses and their surroundings. Social awareness regarding the importance of caring not only for individual historic objects, but also for the character and layout of districts and cities slowly began to grow. Revitalisation activities aimed at revival of the former splendour and cultural value of historic houses in Sopot were launched.

\section{Subject of research}

Revitalisation is a comprehensive process of renewal, integrating activities related to building industry, spatial planning, economics and social policy. Its complexity was broadly described by Dr Andreas Billert [1]. The paper covers mainly architectural and building issues, and presents possible actions to be undertaken, based on modernisation and reconstruction of historic houses, depending on complex conditions, including social and economic ones.

At present it is possible to indicate basic factors affecting the process of revitalisation of historic residential buildings in Sopot. Economic factors, particularly financial limitations, obviously slow down the progress of revitalisation. The city authorities, being aware of the value of the city-resort's historic image have, since 1998, pursued a policy which fosters the revitalisation process. There are local programmes whose aim is to give financial aid to condominiums, mostly in the form of subsidising modernisation works connected with renovation of building elevations. Apart from monetary aid, the local programmes are to promote integration of the activities undertaken by residents and develop responsibility for residential environment.

Social conditioning is more complex. The long years of communism in Poland have, unfortunately, effectively changed the mentality of people by eliminating social thinking which, in this case, denotes lack of care for common good. People do not always identify themselves with their place of residence understood as the building and its surroundings, but only with their own flat. We can observe this phenomenon particularly with regard to communities with a bigger number of people (owners), whose social and economic status is either low or varied. It results in problems with cooperation aimed at achieving common benefits. It is worth to mention another factor, which may negatively affect the revitalisation process, namely that historic buildings, particularly the most valuable ones, cannot be converted or extended in an unrestricted manner. As a result, the residents do not obtain additional benefits, such as additional living area or better lighting of rooms, and thus lose arguments which might support the necessity of modernisation. 
Since 1998 modernisation of numerous historic residential buildings has been performed. Due to the above-mentioned reasons it was done in various degrees. On the one hand there are modernisations limited only to change of roofing and renovation of elevation to the smallest extent. On the other hand, there are also some comprehensive modernisation undertakings. This is usually the case in the situation where the modernised building belongs to one owner or constitutes common property of few cooperating owners.

Only such comprehensive modernisations bring satisfying effects, which has been shown on the example of case analysis in the following part of this article.

\section{Case study}

When commencing the activities which aim at restoring its full value to a historic building, it is necessary, first and foremost, to perform a thorough analysis of its present condition. The subject of analysis and assessment of this condition includes the structure and functional layout, the composition of the form of the building and its elevations, as well as architectural details and urban context. It is important to indicate valuable, original elements of the building substance, which have to be protected, and valueless parts, where activities in excess of typical conservation works are advisable. Although archival design documentation, drawings and photographs may be helpful, the best solution is to have the inventory of the present condition prepared by the future architecture designer. Assessment of technical condition of the building is an indispensable supplement to pre-design works. The initial materials mentioned above constitute the basis for commencement of design works performed by a team of designers, which includes an architect, a constructor and designers of sanitary and electrical installations. In case of particularly valuable buildings (entered into the register of historic monuments), it is also necessary to ensure that a conservator of monuments will participate in the project, as well as to establish the methods and means for performance of conservation works.

The issue has been discussed from the architect's point of view, based on his own experience gained during the modernisation of a historic residential building located in Lipowa Street in Sopot. It is a two-storey building, with partly usable attic and full basement, constructed in 1894. The building has not been entered into the register of historic monuments; it is merely located within the conservation area, which gave certain freedom of action to the architects. Design solutions were agreed upon with the local conservator of monuments at the stage of conceptual and technical design.

\subsection{Functional layout}

On each floor of the analysed building there was originally only one flat. The flats located on the ground and first floor occupied their entire usable area, while in the attic, apart from a flat, there was also a garret accessible from the staircase. After the Second World War all the flats were divided into smaller ones. In the end there were seven flats in the building, and all of them, due to the division, had significant functional defects. The layout of the flat located on the first floor 
was peculiar, seeing that it had one bathroom and two kitchens and was occupied by two families which were not related to each other. It was also difficult to accept the layout of a very small flat situated on the ground floor, where there was only one room and a space which served both as a kitchen and a bathroom.

Another problem was caused by the fact that the functions of the building were not adapted to compass directions, but only to its location in relation to the street. The front façade, which faced the street, had been designed as a representative one and, consequently, the most important rooms were also located on that side of the building. This was usual practice at the turn of the 19th and the 20th century. Unfortunately, in the case of the described building it meant that those rooms were facing north, while on the south side (facing the garden) there were support spaces with small window openings. Lack of access to the garden from the ground floor flat and lack of balconies or terraces on higher storeys was also a significant disadvantage.

At present the building has one owner. It resulted in a possibility to perform comprehensive correction of the functional layout which, in most cases, cannot be done in the situation where there are a few owners. The original functional layout has been restored, i.e. there is only one flat on each floor. In the case in question the "original layout" means only that each storey is now designated for one flat, whereas the functional layout of each flat has been adapted to modern requirements, to the extent made possible by technical-constructional and spatial limitations. It has been assumed that spatial layout of a historic building should determine the possibility of including a certain function in the structure of the building, and not vice versa. This results in the necessity to reach a compromise which, on the one hand, would respect the spatial layout of the building, and on the other hand would find the most advantageous functional solutions, appropriate for the present level of civilisation development and fulfilling the investor's expectations (figs 3 and 4).

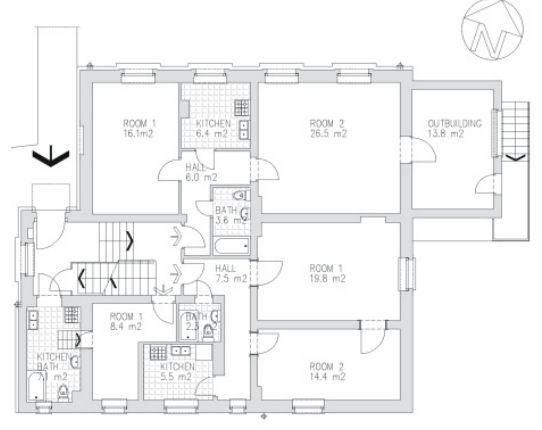

Figure 3: Functional layout before modernization, ground floor plan.

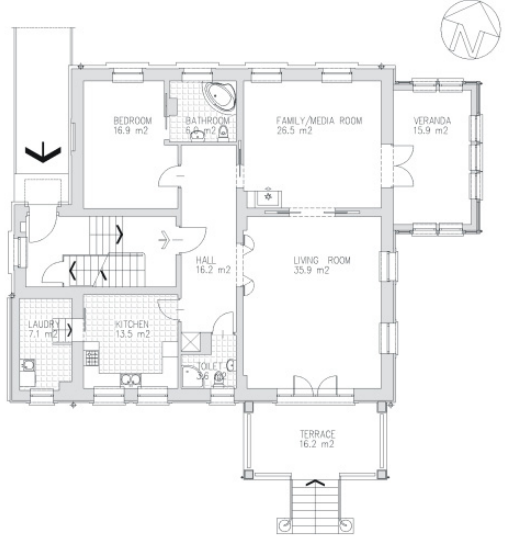

Figure 4: Functional layout after modernization, ground floor plan. 


\subsection{Structure of the building, technical fitting}

Prior to modernisation, the basic structure of the building was in good condition and, ultimately, the majority of it remained original. Changes and construction works were connected with: (1) the correction of functional layout and (2) the planned extension in the east part of the building (side façade).

In the first case construction works consisted mostly in strengthening of the existing wooden floors in the places which were to be under the load of planned walls or the expected useful load. However, despite satisfactory technical condition of the structure, including the floors (lack of visible deflections), the layers of flooring were removed and the floor beams uncovered. Such decision had been made due to extreme wear and tear, devastation of décor elements and the fact that no valuable floorings had been preserved. The second reason was a justified suspicion that in spaces where water is often used (i.e. bathrooms and kitchens) the wooden floor beams might have been damaged by damp resulting from extreme wear of water installation. Changes in the functional layout resulted also in application of steel beams, which constitute floor support in the places where parts of load-bearing walls had been removed, as well as steel heads in re-designed openings. The staircase was preserved in surprisingly good condition, including the original wooden structure of flights of stairs, as well as the details of wooden balustrade.

With regard to the second case - construction of a veranda in the side façade - the architectural form was designed together with an integral structure. Structure of historic verandas in Sopot was made entirely of wood, with wooden filling of spandrel-beam framework. The old verandas did not have thermal insulation, hence their utility values were limited. In the case described here, it was decided to use a modern design solution, i.e. a steel frame structure with reinforced concrete floors. The outer wooden walls of the veranda were designed as shell walls, and thermally insulated in compliance with currently binding norms. Their ventilation was ensured, to prevent out-dropping inside the partition (figs 5-8).

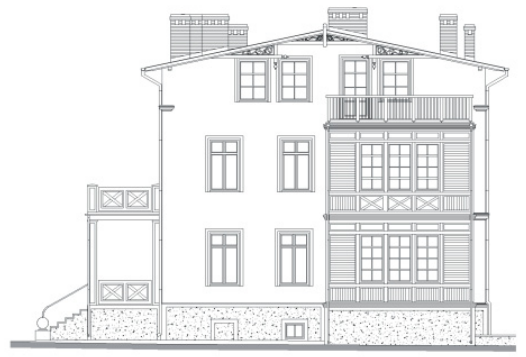

Figure 5: $\quad$ East façade with veranda.

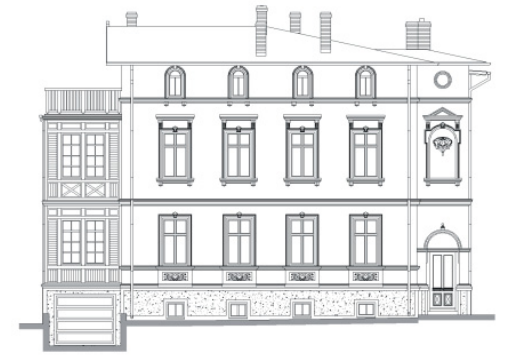

Front façade with veranda. 


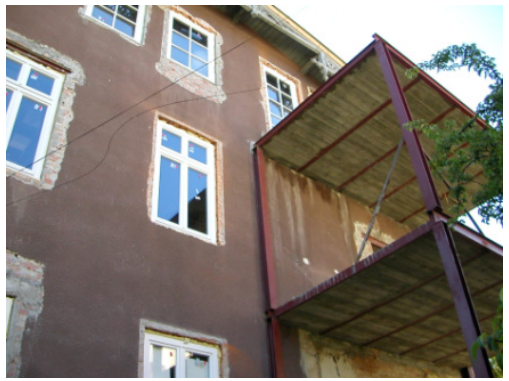

Figure 7: Veranda under construction.

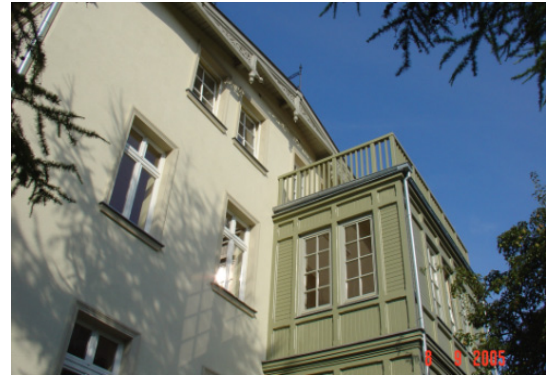

Figure 8: Veranda at present.

Technical equipment of the building, including the installations, was almost entirely worn out. New installation fitting was designed and laid on, its degree of complexity having been adapted to residential functions of the building, with the necessity of energy saving and pro-ecological activities taken into consideration. Methods of insulating residential interiors are related to ensuring low level of energy consumption. In the case described here, due to the fact that traditional plastering techniques were applied to elevations with preserved stucco-work, it was decided to use, in some of the spaces, thermal insulation inside partitions, paying special attention to the configuration of layers, which would prevent outdropping of water vapour and protect walls against damp. Roof insulations (the form and structure of the roof had been preserved in good condition) was adapted to current coefficients of anti-damp and thermal protection.

\subsection{Composition of elevations and form, details and colour scheme}

In residential architecture of Sopot, dating back to the turn of the 19th and the 20th century, we can observe a certain characteristic feature, i.e. a big contrast between front and rear façades of buildings. Front elevations show care for high quality of the composition and architectural detail, while with regard to rear elevations it is difficult to speak of any composition whatsoever - it is a haphazard combination of architectural elements (consisting mainly or, in some cases, solely of window openings), which results directly from functions.

With regard to the front elevation of the described building, renovation works consisted in reparation of façade elements (plaster, stucco-work, profiled window trims) or their replacement (window woodwork, flashing, rainwater pipes). The valuable historic composition of the façade, which is under conservation protection, has remained unchanged.

In respect of the rear elevation such works would not have proved satisfactory. Therefore it was decided to tidy up the entire composition of rear elevation, at the same time ensuring improvement of lighting of residential spaces with natural light. Appropriate lighting of rooms was even more important due to the fact that the rear elevation faces south. Variant research was performed, taking into consideration the size, shape and layout of window openings, as well as their relation to functional layout of the rooms. In the end a 
clear composition of the rear elevation was obtained, with the division between the main part of the façade and the attic emphasised by the horizontal line of cornice. A terrace with steps leading to the garden was designed for the flat on the ground floor and, for the first-floor flat, a terrace supported with poles,

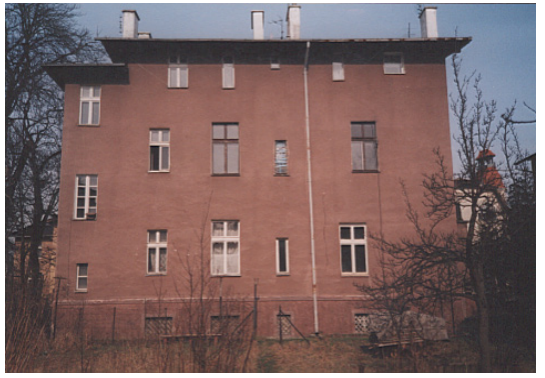

Figure 9: South façade before modernization.

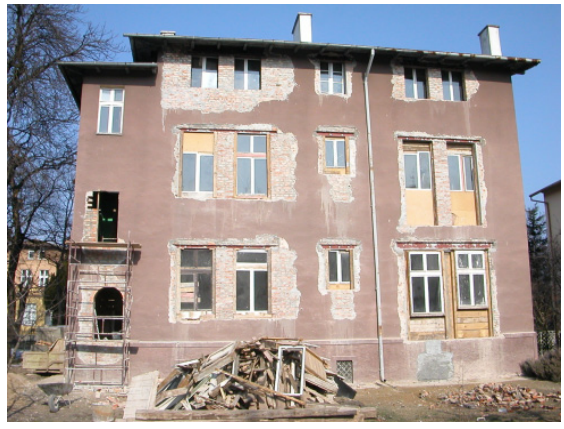

Figure 11: South façade under construction.

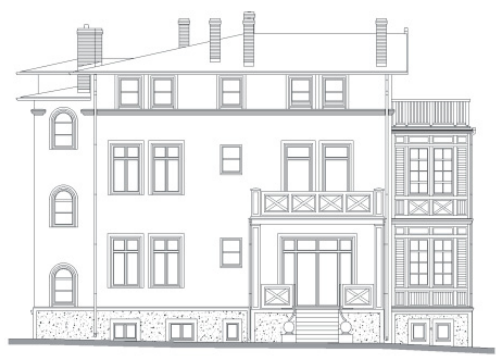

Figure 10: $\quad$ South façade.

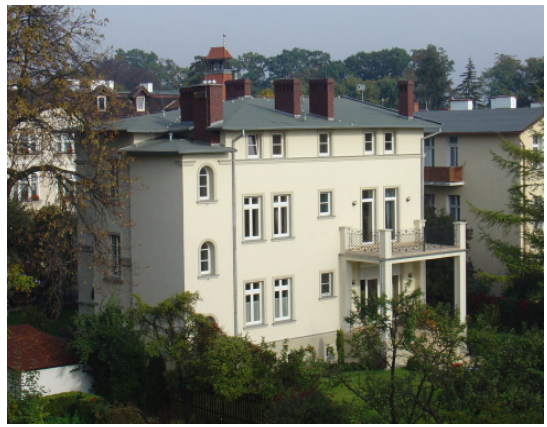

Figure 12: $\quad$ South façade at present.

which made it possible to meet current requirements for residential buildings and, at the same time, break single-planeness and symmetrical layout of the façade. Although full wooden balustrades had been designed, the investor decided to install forged steel balustrades - characteristic for historic architecture of the city, yet, on the whole, too delicate in relation to the entire façade. The illustrations show the architectural design of the rear façade and subsequent stages of its reconstruction (figs 9-12).

In the years following the Second World War a single-storey lean-to was built on original basement walls in the side façade. That part of the building did not have any aesthetic value, and therefore a decision was made to demolish it. The preserved basement walls, as well as the layout of window openings in the side façade evidenced that, in the past, there existed in that place a part of the building, whose dimensions corresponded to those of a veranda. Unfortunately, there were no archival drawings or photographs which would make it possible to 
obtain information on the historic composition of the side façade. Having taken the above into consideration, the pre-design works started with the analysis of historic tenement houses characteristic for Sopot, their architectural form, proportions, division of façades and the details applied. Analyses of historic objects were supplemented with examination of composition and proportions of the side façade in the described building, as well as of forms and materials, which it would be possible to use, and which would be appropriate with regard to architectural, urban and socio-cultural context [2]. In the end a two-storey wooden veranda was designed. Its dimensions and articulation of divisions are characteristic for historic architecture of the city. A terrace with a wooden balustrade, functionally connected with the flat in the attic, was designed for the top of the veranda.

Among the preserved original architectural details of the described building there are wooden elements of the rafter framing, such as the decorative structure of the gable in east elevation, with openwork filler between the rafter and the decorative vertical wooden element placed at the top of the gable, as well as decorative rafter ends. Original stucco-work, cornices and decorative window trims have been preserved in the front and west façades. The front door and the steel canopy placed over it are also original. However, in the rear façade (facing south) no original details had been preserved, and it was decided to use window trims and cornices less decorative in comparison with the original details of the front elevation. The details of wooden veranda walls, including spandrel-beam framework, wall boarding, window woodwork and balustrades, were designed in a moderate way which would not compete with original elements.

Colour is an immanent feature of architecture and, similarly to façade articulation and details, determines its character. In the case described here it was decided to use harmonised light colour scheme, well suited to the urban context of the district. The scheme was based on natural, unsaturated colours, which were applied to façade elements in such a way as to expose façade composition and architectural details (figs 13 and 14).

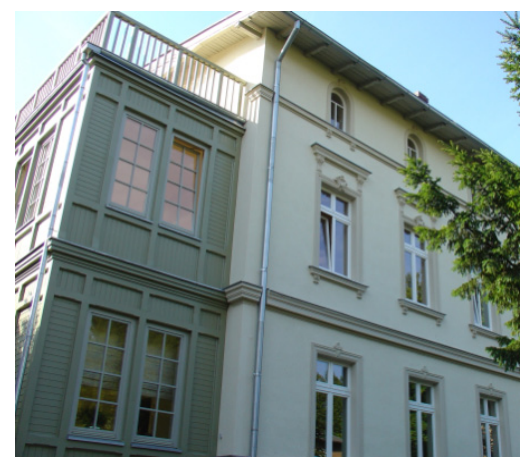

Figure 13: Front façade with veranda at present.

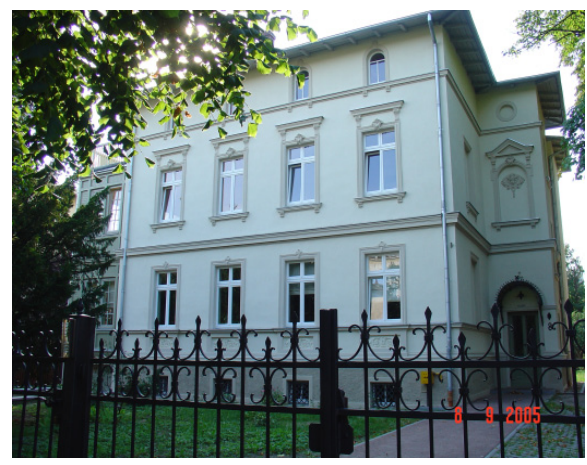

Figure 14: Front façade at present. 


\section{Summary}

The principal aim of modernisation undertakings is to adapt degraded historic buildings and their functional layout to requirements of modern users, ensure their integration with urban context and preservation of historic values to the greatest extent possible. The role of an architect, his knowledge, experience and aesthetic sensitivity are extremely important. Treating the existing architecture with respect and moderation applied in designing should produce the best effects, promoting the exposition of historic and cultural values, as well as harmonious co-existence of original historic elements with newly-designed ones.

An optimal solution seems to be modernisation conducted in as comprehensive a way as possible, including all the elements of historic substance. Cooperation of all parties involved in the revitalisation process, i.e. city authorities, investors, owners and designers is essential. However, as it has been proved in the author's design experience, it is not always possible in practice. Therefore, we cannot establish one appropriate set of rules, but, despite the fact that certain modernisation projects may have common features, each case ought to be examined individually.

\section{References}

[1] Billert A., Centrum staromiejskie w Żarach, problemy, metody i strategie rewitalizacji; research work has been done within the project of the city of Żory, financed from the European Union funds and concerned the issue of city centre revitalization, Stubice 2004

[2] Pokrzywnicka K., Juchnevic K., Friendly innovative health resort - Case study, International Scientific Conference Urban Landscape Renewal-ULAR 6, Gliwice 2012, pp. 351-356 